\title{
Seasonal Alteration in Physico-Chemical characteristics of Ground Water Quality Around Amarkantak Thermal Power Plant, Chachai, Madhya Pradesh, India.
}

\author{
Ashok Kumar Tripathi ${ }^{1}$, M. K. Bhatnagar ${ }^{2}$, Prachi Bhatnagar ${ }^{3}$, \\ ${ }^{1}$ Research Scholar ${ }^{2}$ Head, Department of Chemistry, Pt. SNS Govt. PG College Shahdol, (M. P.) 484001, India. \\ ${ }_{3}^{3}$ DIET, Shahdol, (M. P.), India
}

\begin{abstract}
The ground water quality is relatively based on the geo-morphological and environmental conditions, which are the key source to assess the alteration in physico chemical properties of water quality of the system and surroundings. The current study is an outcome of continual observation and physico- chemical analysis of water samples collected in a fix time of intervals during different seasons of year from the radius of 3-4 km considering Amarkantak Thermal Power Station in Chachai (M.P.), as centre of study point and impartible source of Environmental pollutants. In order to scrutinize the Physico-Chemical Properties of Surface water to assess the suitability for domestic purposes, water samples were collected from five different locations in the surrounding of ATPS, Chachai in summer, monsoon and winter seasons. The ground water samples were analysed for 14 physico-chemical parameters. Significant changes have been observed in the water quality during the year. the $\mathrm{pH}$ ranged from 7.12- 8.30, conductivity differed 231-1392 $(\mu \mathrm{s} / \mathrm{cm})$, TDS ranged 148-891 ppm, however fluctuation was higher in Total Hardness from 118-512 ppm, but changes in Ca and $\mathrm{Mg}$ hardness is noticeable. Alkalinity was reported minimum 136 and maximum 380 ppm, while the concentration of chloride varied from 14-210 ppm. The concentration of nitrate observed in between 8-58 ppm, sulphate ranged 24-230 ppm and phosphate found within the permissible limits in all sample points. The studied physico-chemical parameters of 3 locations out of 5 sampling station reveal that, water quality is appropriate for domestic and drinking purpose except two locations due to higher limits of turbidity, conductivity, TDS, hardness, Alkalinity and Nitrate concentration against BIS: 10500 standards.
\end{abstract}

Key Words: ATPS Chachai, Ground Water, Seasonal Alteration, Physico-chemical Pollutants.

\section{Introduction}

As Per World Health Organization "Water intended for human consumption must be free from harmful micro organism, toxic substances, excessive amount of minerals and organic matter" [1]. The Amarkantak Thermal Power Plant was operational since 1977 with existing total 450 MW (2x120MW + 1x210MW) generations Capacity as a coal based electricity generation system. Ground Water Pollution from thermal power ash-dust is reported at many places in the country by Central Pollution Control Board. At Chachai Thermal power Plant ash-dust was dumped near thermal power station, which needs scientific studies to ascertain possible pollution in ground water system of the area and around Amarkantak Thermal Power station, is suggested to study ground water pollution around the plant [2].

Researchers are continuously focusing about water pollution assessment in India and over the world. A study report suggested that the Jal Mahal Lake water was most polluted due to high $\mathrm{pH}$, hardness, alkalinity, free Carbon dioxide and Zinc content and a low level of dissolved oxygen [3]. Heavy metal contamination of ground water quality was studied in Uyyakondan channel of Tamil Nadu and found that Nickel and lead was excess present in few locations as compared to the permissible standard limit [4]. Water samples of ten villages subjected to physico-chemical parameters were analyzed and compared with different prescribed standards to assess the bore well drinking water quality, resulted that all the stations are having excess of TDS, Alk, TH, Ca, $\mathrm{Mg}, \mathrm{Na}, \mathrm{K}, \mathrm{Cl}$ [5]. Similarly the evaluation study of water Pollution level at the Rewa city, M.P., India identified the effect of environmental changes on ground water and surface water quality of the area as non suitability of some water samples for drinking purposes [6].

Human needs are growing rapidly and the need for water is also growing. Much of the current concern with regards to environmental quality is focused on water because of its importance in maintaining the human health and health of the ecosystem [7]. Earth surface is acting as an effective filtrate to filter out particulate matters like leaves, soils, bugs, dissolved chemicals and gases which also occurs in large concentrations to change the physico-chemical properties of groundwater [8]. Assessment of ground water quality of rural parts of kapadwanj was also studied for the determination of the physio-chemical analysis of ground water carried out from twenty sampling stations of rural parts of Kapadwanj region during 2012 in order to assess water quality index [9]. 


\section{Study Site}

The Amarkantak Thermal Power Station in Chachai (M.P.) is a link in Korba-Amarkantak-Satpura power chain and is situated at $23^{\circ} 10^{\prime} 04^{\prime \prime} \mathbf{N}$ and $81^{\circ} 39^{\prime} 15^{\prime \prime} \mathbf{E}$ falling in Survey of India toposheet nos. 64E, 64F\&I. It is interconnected to the $220 \mathrm{KV}$ lines Madhya Pradesh grid line and the Rihand system of Uttar Pradesh through $132 \mathrm{KV}$ lines [10].

Table No.1: Study Site and Location with Latitude and Longitude of Ground Water Sample Points.

\begin{tabular}{|c|c|c|c|}
\hline S. No. & Area/Location & Sample ID & Geographical Position \\
\hline 1 & ATPS COLONY & CHW-1 & $23^{\circ} 10^{\prime} 21^{\prime \prime} \mathbf{N}$ and 81 $39^{\circ} 20^{\prime \prime} \mathbf{E}$ \\
\hline 2 & KALHORI VILLAGE & CHW-2 & $23^{\circ} 10^{\prime} 22^{\prime \prime} \mathbf{N}$ and $81^{\circ} 38^{\prime} 07^{\prime \prime} \mathbf{E}$ \\
\hline 3 & VIVEK NAGAR & CHW-3 & $23^{\circ} 09^{\prime} 37^{\prime \prime} \mathbf{N}$ and $81^{\circ} 37^{\prime} 35^{\prime \prime} \mathbf{E}$ \\
\hline 4 & MEDIYARASH & CHW-4 & $23^{\circ} 08^{\prime} 39^{\prime \prime} \mathbf{N}$ and 81 $39^{\circ} 18^{\prime \prime} \mathbf{E}$ \\
\hline 5 & CHACHAI BASTI & CHW-5 & $23^{\circ} 09^{\prime} 42^{\prime \prime} \mathbf{N}$ and $81^{\circ} 40^{\prime} 07^{\prime \prime} \mathbf{E}$ \\
\hline
\end{tabular}

The key map of study area along with identified locations for ground water sampling around Amarkantak Thermal Power Plant, Chachai, Madhya Pradesh, are displayed in fig.1.

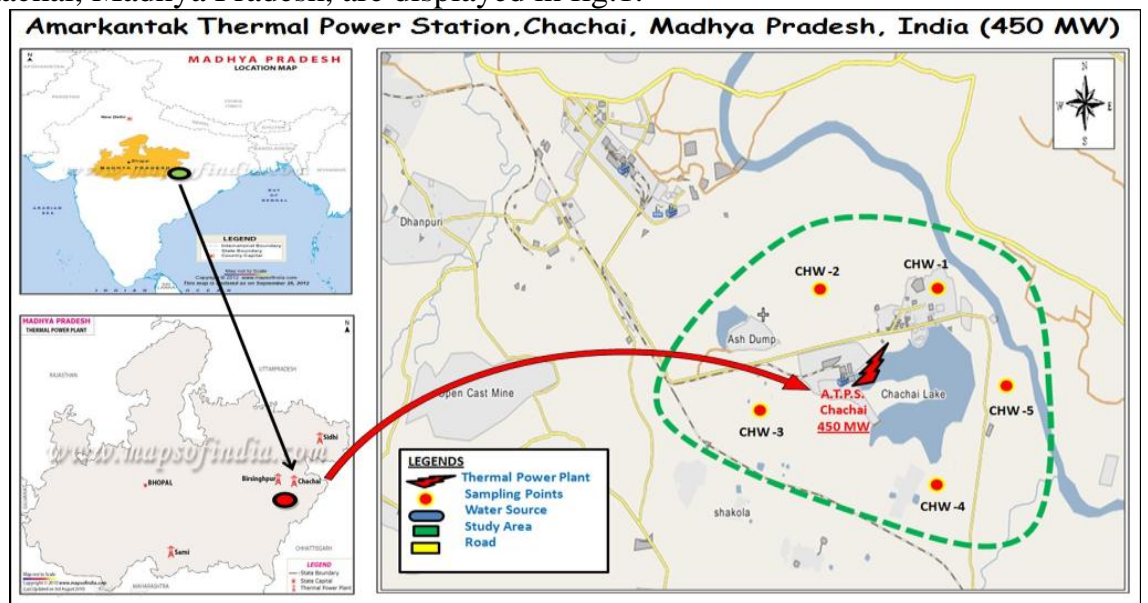

Fig. -1: Key Map of the Study Area (ATPS, Chachai, Madhya Pradesh) with identified water sampling location.

\section{Material and Methods}

Total Fifteen numbers of water samples were collected followed by 5 samples in three seasons from different surrounding locations around Amarkantak thermal power plant, Chachai considering it as centre of the current study. The physico-chemical analyses of the samples were performed as per standard methodology prescribed in APHA, 1989 [11] and BIS: 3025, 1987 (Reaffirmed 2003). The temperature of collected samples was measured on the rise in the mercury levels on a graduated scale, simultaneously by the electronic method of temperature sensitive electrodes in a thoroughly shaken sample and the reading $\left(\mathrm{in}^{0} \mathrm{C}\right)$ were noted down. $\mathrm{pH}$ of the samples were observed with a calibrated instrument while conductivity was measured with microprocessor based analyser and reported as corrected values in $\mu \mathrm{s} / \mathrm{cm}$ at $25^{\circ} \mathrm{C}$. The turbidity of the samples were analyzed with HACH-2100Q and reported in NTU. The Alkalinity, hardness and chloride concentration were measured with volumetric estimation and reported in $\mathrm{mg} / \mathrm{l}$. However, Sulphate, Nitrate, Silica and Phosphate were evaluated by using spectro-photometric methods of WTW Photo-lab 6100 VIS.

\section{Result and Discussion}

The Physico-chemical data of the 5 number of ground water samples collected in three seasons (summer, monsoon and winter) from different locations in the surrounding of Amarkantak thermal power plant, Chachai (M.P.) for 14 physico-chemical parameters are presented in Table-2, Table-3, Table-4 and correlation Matrix (Table-5) respectively. The obtained results were compared with Standard prescribed under BIS 10500:2012 are summarised hereunder [12]. 
Table No. 2: Physico-Chemical Analysis of Ground Water Sample in summer.

\begin{tabular}{|c|c|c|c|c|c|c|c|c|c|}
\hline \multicolumn{2}{|c|}{ S. No. } & Parameters & Unit & BIS-10500 & CHW-1 & CHW-2 & CHW-3 & CHW-4 & CHW-5 \\
\hline \multirow{7}{*}{ 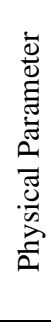 } & 1 & Taste & - & Agreeable & Agreeable & Agreeable & Agreeable & Agreeable & Agreeable \\
\hline & 2 & Odour & - & Odourless & Odourless & Odourless & Odourless & Odourless & Odourless \\
\hline & 3 & Colour & Hazen & 5 & 2 & 4 & 2 & 1 & 2 \\
\hline & 4 & Turbidity & NTU & 5 & 2.32 & 11.8 & 3.10 & 8.87 & 1.21 \\
\hline & 5 & Conductivity & $\mu \mathrm{s} / \mathrm{cm}$ & 750 & 810 & 1245 & 231 & 741 & 384 \\
\hline & 6 & TDS & $\mathrm{mg} / \mathrm{l}$ & 500 & 502 & 747 & 148 & 489 & 234 \\
\hline & 7 & $\mathrm{pH}$ & - & $6.5-8.5$ & 7.80 & 8.30 & 7.92 & 8.15 & 7.36 \\
\hline \multirow{7}{*}{ 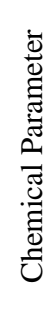 } & 8 & $\mathrm{TH}$ & $\mathrm{mg} / \mathrm{l}$ & 300 & 350 & 480 & 118 & 390 & 218 \\
\hline & 9 & ALK & $\mathrm{mg} / \mathrm{l}$ & 200 & 136 & 198 & 162 & 192 & 154 \\
\hline & 10 & $\mathrm{Cl}$ & $\mathrm{mg} / \mathrm{l}$ & 250 & 92 & 196 & 48 & 46 & 56 \\
\hline & 11 & $\mathrm{SO}_{4}$ & $\mathrm{mg} / \mathrm{l}$ & 200 & 108 & 196 & 32 & 212 & 86 \\
\hline & 12 & $\mathrm{NO}_{3}$ & $\mathrm{mg} / \mathrm{l}$ & 45 & 16 & 52 & 12 & 54 & 20 \\
\hline & 13 & $\mathrm{Si}$ & $\mathrm{mg} / \mathrm{l}$ & - & 15.0 & 30.9 & 17.2 & 25.1 & 20.0 \\
\hline & 14 & $\mathrm{PO}_{4}$ & $\mathrm{mg} / \mathrm{l}$ & 1 & 0.07 & 0.02 & 0.03 & 0.06 & 0.04 \\
\hline
\end{tabular}

Table No. 3: Physico-Chemical Analysis of Ground Water Sample in Monsoon.

\begin{tabular}{|c|c|c|c|c|c|c|c|c|c|}
\hline \multicolumn{2}{|c|}{ S. No. } & Parameters & Unit & BIS-10500 & CHW-1 & CHW-2 & CHW-3 & CHW-4 & CHW-5 \\
\hline \multirow{7}{*}{ 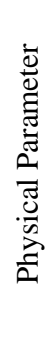 } & 1 & Taste & - & Agreeable & Agreeable & Agreeable & Agreeable & Agreeable & Agreeable \\
\hline & 2 & Odour & - & Odourless & Odourless & Odourless & Odourless & Odourless & Odourless \\
\hline & 3 & Colour & Hazen & 5 & 2 & 6 & 3 & 2 & 2 \\
\hline & 4 & Turbidity & NTU & 5 & 4.17 & 25.29 & 4.89 & 10.87 & 3.1 \\
\hline & 5 & Conductivity & $\mu \mathrm{s} / \mathrm{cm}$ & 750 & 920 & 1392 & 300 & 1013 & 412 \\
\hline & 6 & TDS & $\mathrm{mg} / \mathrm{l}$ & 500 & 570 & 891 & 201 & 638 & 268 \\
\hline & 7 & $\mathrm{pH}$ & - & $6.5-8.5$ & 7.20 & 7.86 & 7.14 & 7.67 & 7.20 \\
\hline \multirow{7}{*}{ 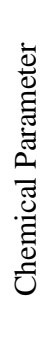 } & 8 & $\mathrm{TH}$ & $\mathrm{mg} / \mathrm{l}$ & 300 & 418 & 512 & 154 & 510 & 236 \\
\hline & 9 & ALK & $\mathrm{mg} / \mathrm{l}$ & 200 & 150 & 288 & 178 & 211 & 169 \\
\hline & 10 & $\mathrm{Cl}$ & $\mathrm{mg} / \mathrm{l}$ & 250 & 102 & 210 & 52 & 20 & 60 \\
\hline & 11 & $\mathrm{SO}_{4}$ & $\mathrm{mg} / \mathrm{l}$ & 200 & 64 & 154 & 24 & 230 & 62 \\
\hline & 12 & $\mathrm{NO}_{3}$ & $\mathrm{mg} / \mathrm{l}$ & 45 & 22 & 58 & 11 & 50 & 22 \\
\hline & 13 & $\mathrm{Si}$ & $\mathrm{mg} / \mathrm{l}$ & - & 19.3 & 37.1 & 0.0 & 27.1 & 23.6 \\
\hline & 14 & $\mathrm{PO}_{4}$ & $\mathrm{mg} / \mathrm{l}$ & 1 & 0.09 & 0.03 & 0.04 & 0.08 & 0.05 \\
\hline
\end{tabular}

Table No. 4: Physico-Chemical Analysis of Ground Water Sample in winter.

\begin{tabular}{|c|c|c|c|c|c|c|c|c|c|}
\hline \multicolumn{2}{|c|}{ S. No. } & Parameters & Unit & BIS-10500 & CHW-1 & CHW-2 & CHW-3 & CHW-4 & CHW-5 \\
\hline \multirow{7}{*}{ 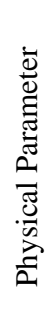 } & 1 & Taste & - & Agreeable & Agreeable & Agreeable & Agreeable & Agreeable & Agreeable \\
\hline & 2 & Odour & - & Odourless & Odourless & Odourless & Odourless & Odourless & Odourless \\
\hline & 3 & Colour & Hazen & 5 & 3 & 5 & 3 & 2 & 3 \\
\hline & 4 & Turbidity & NTU & 5 & 3.5 & 12.8 & 3.83 & 6.96 & 2.84 \\
\hline & 5 & Conductivity & $\mu \mathrm{s} / \mathrm{cm}$ & 750 & 834 & 1145 & 275 & 916 & 397 \\
\hline & 6 & TDS & $\mathrm{mg} / \mathrm{l}$ & 500 & 517.08 & 733 & 184 & 577 & 258 \\
\hline & 7 & $\mathrm{pH}$ & - & $6.5-8.5$ & 7.45 & 7.98 & 7.12 & 7.88 & 7.90 \\
\hline \multirow{7}{*}{ 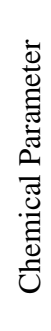 } & 8 & $\mathrm{TH}$ & $\mathrm{mg} / \mathrm{l}$ & 300 & 410 & 480 & 118 & 218 & 268 \\
\hline & 9 & ALK & $\mathrm{mg} / \mathrm{l}$ & 200 & 142 & 260 & 168 & 250 & 380 \\
\hline & 10 & $\mathrm{Cl}$ & $\mathrm{mg} / \mathrm{l}$ & 250 & 95 & 198 & 44 & 14 & 52 \\
\hline & 11 & $\mathrm{SO}_{4}$ & $\mathrm{mg} / \mathrm{l}$ & 200 & 78 & 182 & 38 & 202 & 74 \\
\hline & 12 & $\mathrm{NO}_{3}$ & $\mathrm{mg} / \mathrm{l}$ & 45 & 20 & 50 & 8 & 48 & 18 \\
\hline & 13 & $\mathrm{Si}$ & $\mathrm{mg} / \mathrm{l}$ & - & 14.2 & 32.4 & 21.2 & 25.1 & 21.9 \\
\hline & 14 & $\mathrm{PO}_{4}$ & $\mathrm{mg} / \mathrm{l}$ & 1 & 0.08 & 0.02 & 0.03 & 0.05 & 0.04 \\
\hline
\end{tabular}


The Correlation matrix of various Physico-chemical parameters reveals a positive correlation among some parameters. The correlation coefficient values of Conductivity and TDS (0.998) along with hardness $(0.900$ and 0.908) are positively correlated and signify the influence of dissolved solids in the ground water. The high electrical conductivity values are due to concentration of ionized substances present in water and due to higher total dissolved salts. The matrix shows fairly high correlation of Sulphate and Nitrate $(0.928)$ as well as Turbidity with Silica (0.888). Also negative correlation of $\mathrm{PO}_{4}$ is observed with NTU, pH, ALK, Cl, $\mathrm{NO}_{3}$ and Silica.

Table no.5: Correlation Matrix for Different Physico-Chemical Quality Parameters.

\begin{tabular}{|c|c|c|c|c|c|c|c|c|c|c|c|c|}
\hline Colour & $\begin{array}{c}\text { Colour } \\
\mathbf{1}\end{array}$ & NTU & Cond. & TDS & $\mathrm{pH}$ & $\mathrm{TH}$ & ALK & $\mathrm{Cl}$ & $\mathrm{SO}_{4}$ & $\mathrm{NO}_{3}$ & $\mathrm{Si}$ & $\mathrm{PO}_{4}$ \\
\hline NTU & 0.735 & 1 & & & & & & & & & & \\
\hline Cond. & 0.735 & 0.775 & 1 & & & & & & & & & \\
\hline TDS & 0.534 & 0.796 & 0.998 & 1 & & & & & & & & \\
\hline $\mathrm{pH}$ & 0.543 & 0.449 & 0.512 & 0.511 & 1 & & & & & & & \\
\hline T H & 0.209 & 0.659 & 0.900 & 0.908 & 0.445 & 1 & & & & & & \\
\hline ALK & 0.417 & 0.437 & 0.233 & 0.255 & 0.439 & 0.195 & 1 & & & & & \\
\hline $\mathrm{Cl}$ & 0.465 & 0.668 & 0.747 & 0.693 & 0.370 & 0.638 & 0.187 & 1 & & & & \\
\hline $\mathrm{SO}_{4}$ & 0.832 & 0.588 & 0.747 & 0.753 & 0.687 & 0.685 & 0.303 & 0.236 & 1 & & & \\
\hline $\mathrm{NO}_{3}$ & 0.122 & 0.800 & 0.822 & 0.836 & 0.664 & 0.731 & 0.390 & 0.443 & 0.928 & 1 & & \\
\hline $\mathrm{Si}$ & 0.351 & 0.888 & 0.645 & 0.665 & 0.438 & 0.527 & 0.556 & 0.590 & 0.625 & 0.815 & 1 & \\
\hline $\mathrm{PO}_{4}$ & 0.674 & -0.302 & 0.083 & 0.079 & -0.310 & 0.255 & -0.375 & -0.386 & 0.032 & -0.112 & -0.501 & 1 \\
\hline
\end{tabular}

The recorded value of colour is acceptable against prescribed desirable limit of 5.0 Hazen except CHW-2 while turbidity is recorded in higher side for CHW-2 and CHW-4 beside desirable limit of 5.0 NTU is shown in Fig.2 and 3 .

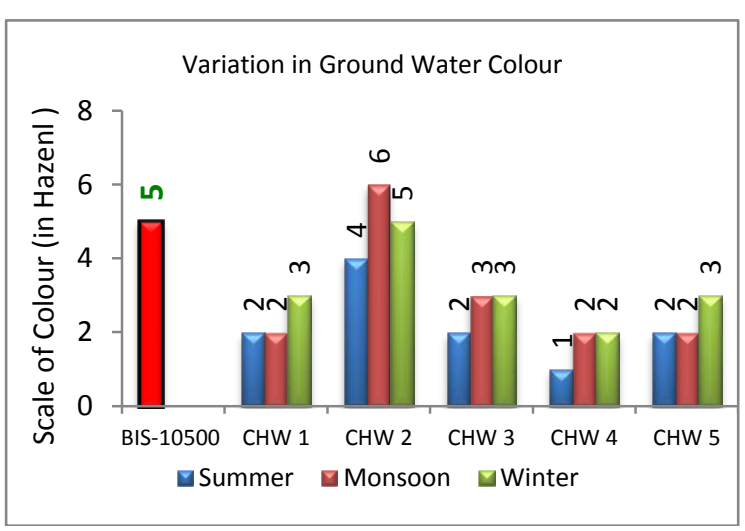

Fig.-2 Distribution of Colour

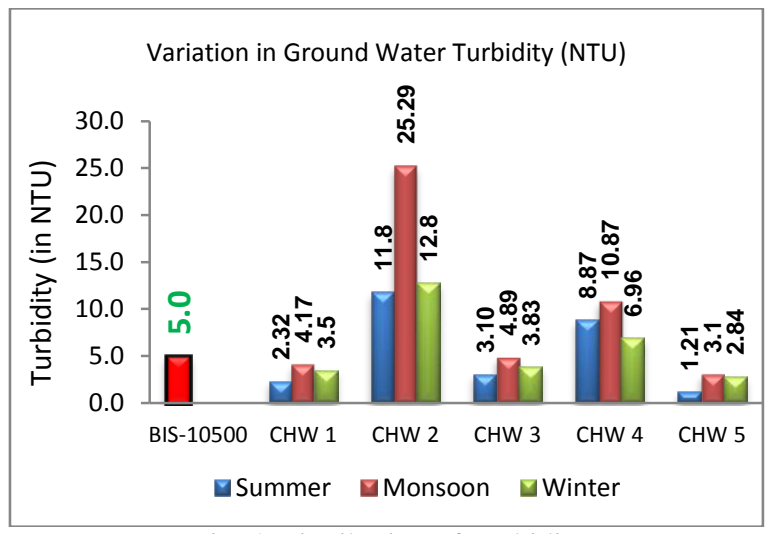

Fig.-3 Distribution of Turbidity

The Conductivity of the groundwater is varying from 231-1392 $(\mu \mathrm{s} / \mathrm{cm})$ while TDS ranged from 148 - 891 ppm against the prescribed limit of $750 \mu \mathrm{s} / \mathrm{cm}$ and $500 \mathrm{ppm}$.

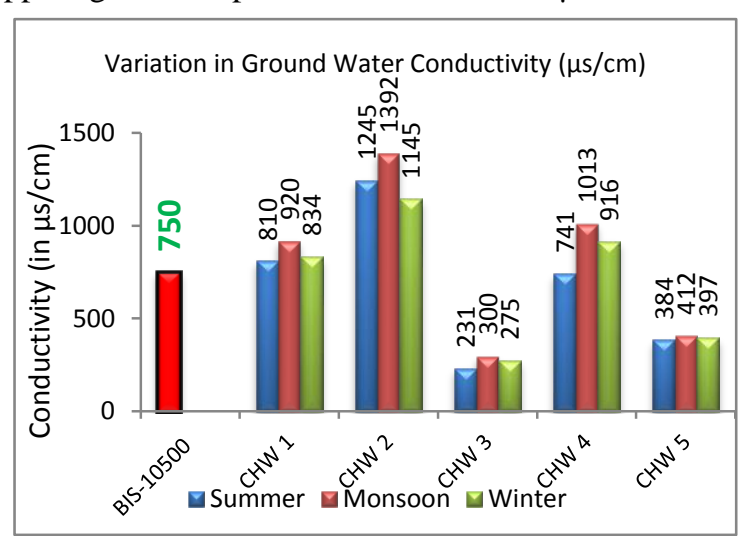

Fig.-4 Distribution of Conductivity

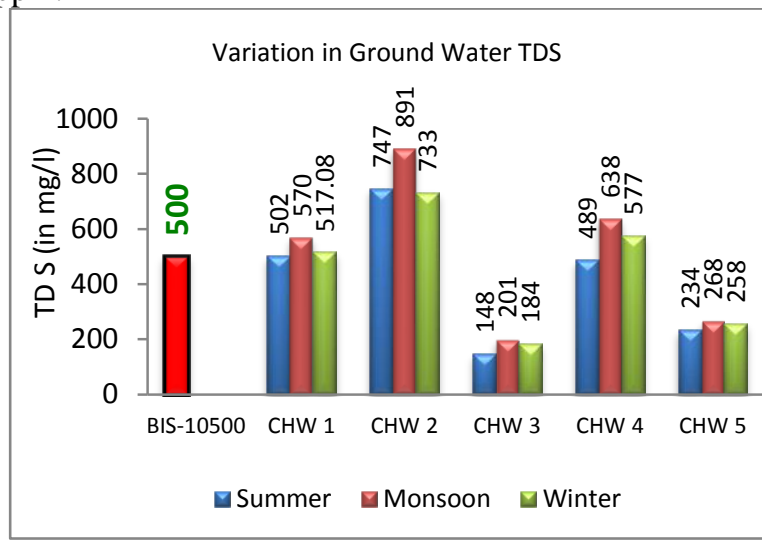

Fig.-5 Distribution of TDS

The Higher Conductivity and TDS for CHW-2 and CHW-4 shown in fig.4 and 5, indicate that salinity of the water is higher in respect to the other location. $\mathrm{pH}$ value is an important factor in maintaining the carbonate and bicarbonate levels in water. $\mathrm{pH}$ is a term used to indicate the alkalinity or acidity of a substance [13]. The $\mathrm{pH}$ values recorded within the range of 7.12-8.30 for groundwater samples and are found to within the Desirable 
limit of 6.5-8.5ppm in all the sampling stations is shown in fig.6 . There are no abnormal Changes observed in $\mathrm{pH}$ of groundwater.

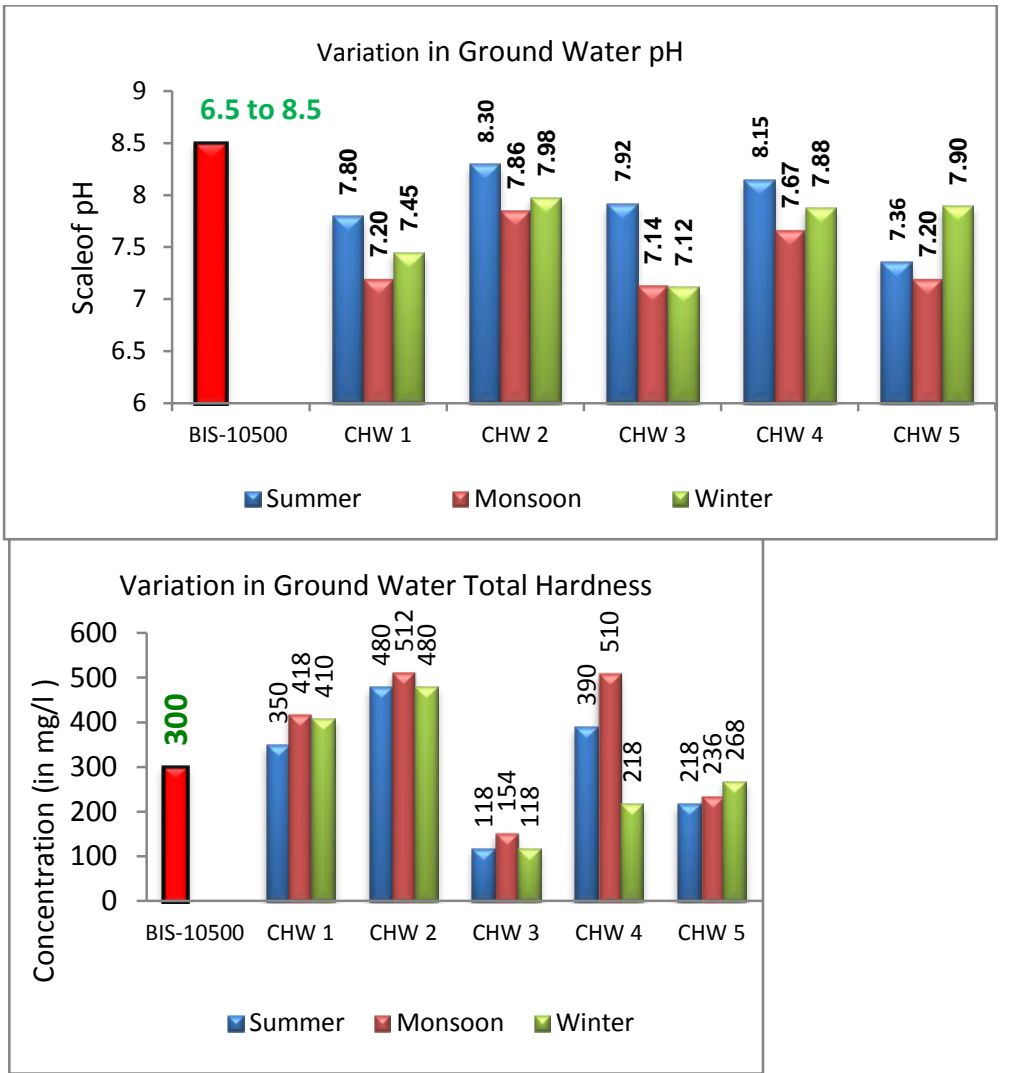

Fig.-6 Distribution of $\mathrm{pH}$

Fig.-7 Distribution of Total Hardness

The total hardness range (fig.7) is from $118 \mathrm{mg} / \mathrm{l}$ to $512 \mathrm{mg} / \mathrm{l}$. hardness of the water is dependable factor of Calcium and magnesium contents in carbonate form, which ultimately knew as total hardness. Sample no CHW1,2 , and 3 reported as higher hardness concentration against the desirable range for total hardness is $300 \mathrm{mg} / \mathrm{l}$. Total alkalinity in the collected ground water samples ranged from $136 \mathrm{mg} / \mathrm{l}$ to $380 \mathrm{mg} / \mathrm{l}$. sample site CHW-2, 4 and 5 recorded as higher alkaline water (fig.8) while other two were under the desirable limits of $200 \mathrm{mg} / \mathrm{l}$.

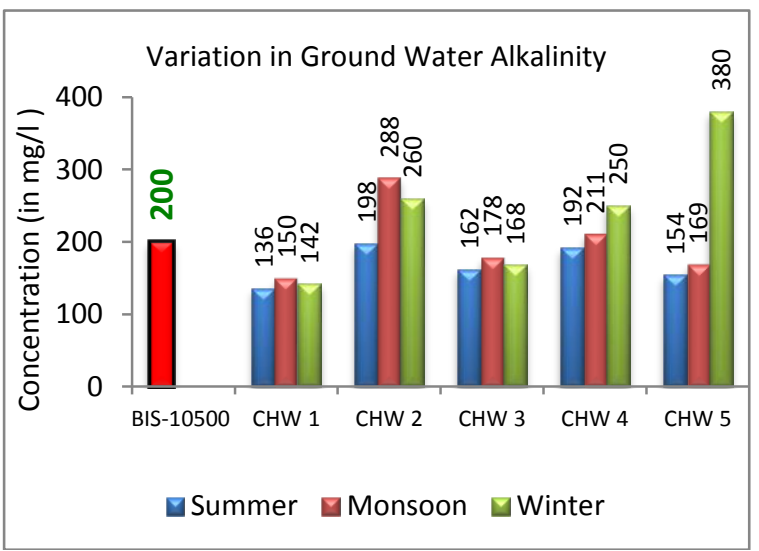

Fig.-8 Distribution of Alkalinity

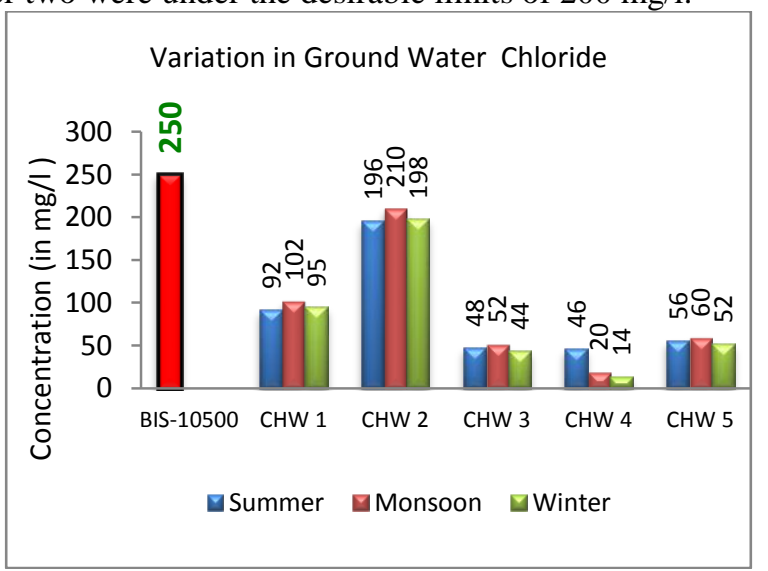

Fig.-9 Distribution of Chloride

The chlorides concentration in the current study reported between 14.0 to $210 \mathrm{mg} / \mathrm{l}$. the chloride ion concentration in the entire ground water sample reported under the desirable limit for chloride $(<250 \mathrm{mg} / \mathrm{l})$ for Drinking water shown in fig.9.

Sulphate ranged from $24 \mathrm{mg} / \mathrm{l}$ to $230 \mathrm{mg} / \mathrm{l}$. The higher sulphate concentration reported within the desirable limit (200 mg/l) except CHW-4, shown in fig.10. Whereas the Nitrate recorded between $8 \mathrm{mg} / \mathrm{l}$ to $58 \mathrm{mg} / \mathrm{l}$. one 
groundwater location (CHW-2) is recorded more than the maximum permissible limit of $45 \mathrm{mg} / \mathrm{l}$ mentioned in fig.11.

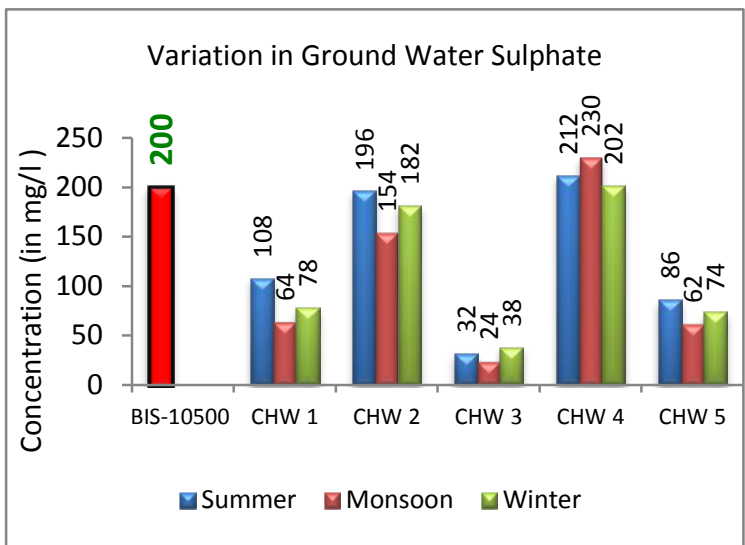

Fig.-10 Distribution of Sulphate

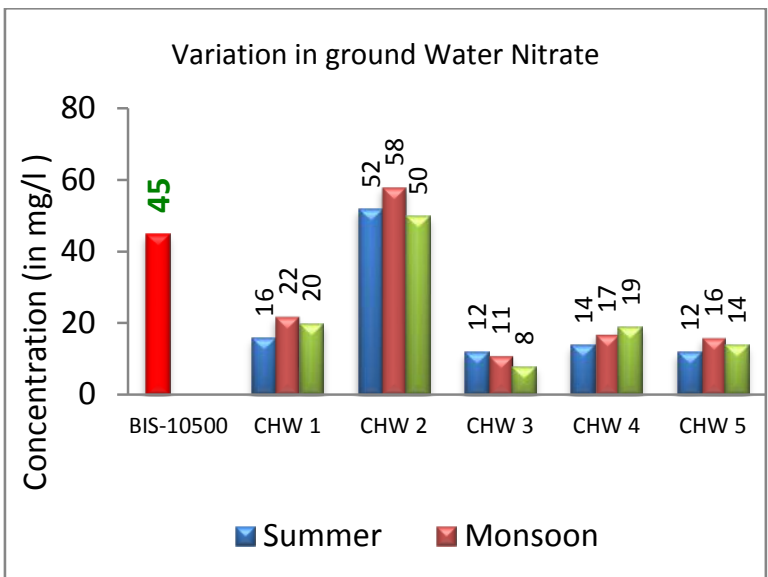

Fig.-11 Distribution of Nitrate

In the present study phosphate ranged from $0.02 \mathrm{mg} / \mathrm{l}$ to $0.09 \mathrm{mg} / \mathrm{l}$. entire ground water samples were reported within the maximum permissible limit $(1.0 \mathrm{mg} / \mathrm{l})$ exhibited in fig. 12 .

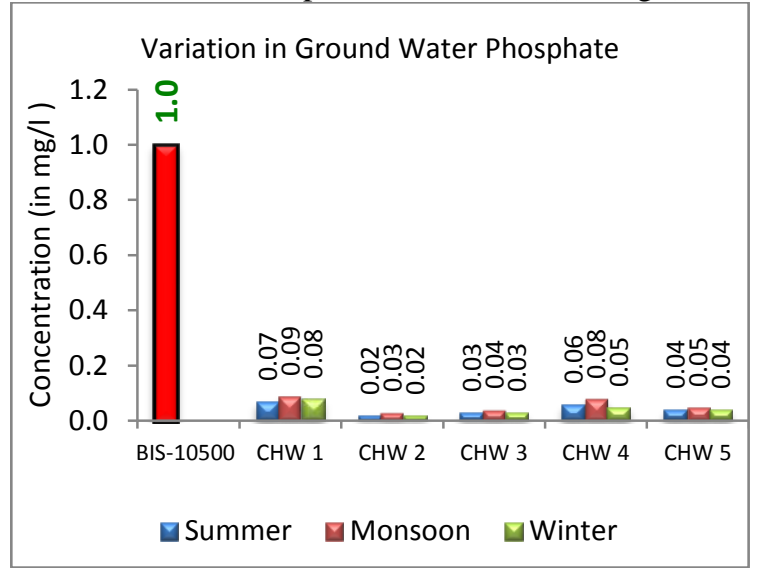

Fig.-12 Distribution of Phosphate

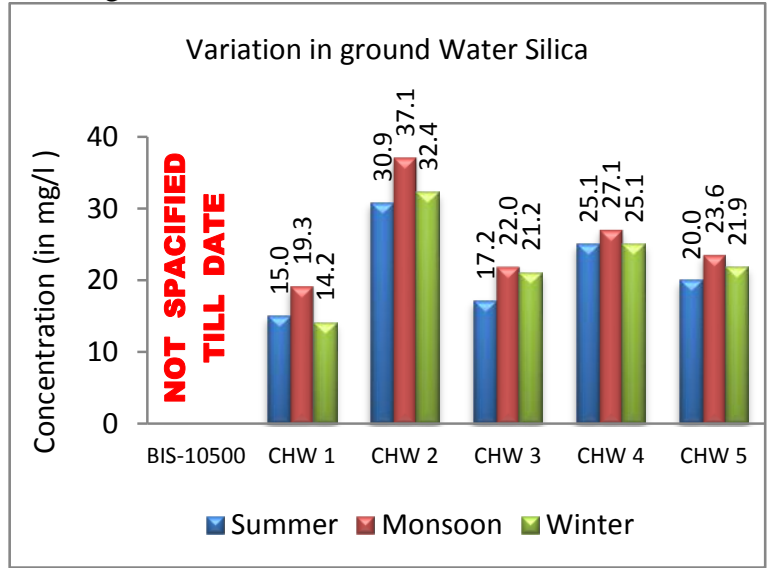

Fig.-13 Distribution of Silica

As well as the silica concentration in ground water samples reported from $14.2 \mathrm{mg} / \mathrm{l}$ to $37.1 \mathrm{mg} / \mathrm{l}$ shown in fig.13. Although there are no any written guidelines established by BIS-10500 or WHO for the permissible concentration of silica in drinking water till date but in the Australian Drinking Water Guidelines (ADWG Vol.6:2011) $80 \mathrm{mg} / \mathrm{l}$ prescribed as maximum permissible limit.

\section{Conclusion}

On the basis of physic chemical analysis of water samples, it is concluded that significant seasonal variations were observed during the year. Results were compared with the prescribed limits for drinking water. However all sampling stations recorded as suitable and within the limits for domestic as well as drinking purpose except location CHW-02. The fluctuation in physic-chemical Parameters of the CHW-02 may be an imparted effect of adjacent fly ash dyke of thermal power Station. In Kalhori village values of conductivity, hardness, TDS, turbidity, alkalinity and Nitrate were reported above against the prescribed limits of BIS10500:2012.

\section{Reference}

[1] World Health Organization(WHO), International Standards for drinking water, Geneva, WHO, 1998

[2] CGWB, Annual report of central Ground Water Board, Ministry of Water Resource, Govt. of india, 2010 , pp16.

[3] Shrivastva N, Agarwal M and Tyagi A., study of physic-chemical characterstics of water bodies around jaipur. J. Environ. Biol., 2003, 24(2): 178-180.

[4] Sirajudeen, J., Manikandan, S. A. and Naveen., J., Seasonal variation of heavy metal contamination of ground water inUyyakond an channel of Tiruchirappalli district (Tamil Nadu). Der Chemica Sinica, 2012, 3(5):1113-1119.

[5] Ramesha, M., Dharmaraja, E. and Ravindra Raj Advances in Applied Science Research, 2012, 3 (3):1709-1713

[6] Bhatnagar, M.K., Singh, M., Bhatnagar, P. and Tripathi, A., Physico-chemical Analysis of some water samples in Rewa city (M.P.) India. Jr. Poll. Res., 2012, 31 (2): 83-85.

[7] Mathiyalagan Kiruthika1, Ramasamy Elayaperumal, Murugan Srimathi, Advances in Applied Science Research, 2012, 3 (5):33503353. 
[8] Shankar. K, Aravindan. S and Rajendran. S, Advances in Applied Science Research, 2011, 2 (5):92-103.

[9] Pandya, S.N., Rana, A. K. Bhol D.K. and Thakor, F.J., Asessment of Ground Water Quality of Rural Parts of Kapadwanj and its Impact on Human Health. Curr. World Environ. 2013, Vol. 8(1), 153-156.

[10] Banerjee S.K., Kashyap M.K., Journal of Environmental Studies and Policy, 1999, 2(2): 117-124.

[11] APHA (American Public Health Association). Standard methods for Examination of water and waste water, 16th Edn APHA -WPCE - AWWA, Washington (1985).

[12] IS: 10500, Bureau of Indian standard, Specification for drinking water New Delhi (1983) reaffirmed (IS: 10500, 2012).

[13] Archana Singh, Suman Malik and Mamta Bhattacharya Der Chemica Sinica, 2011, 2(6):269-272. 